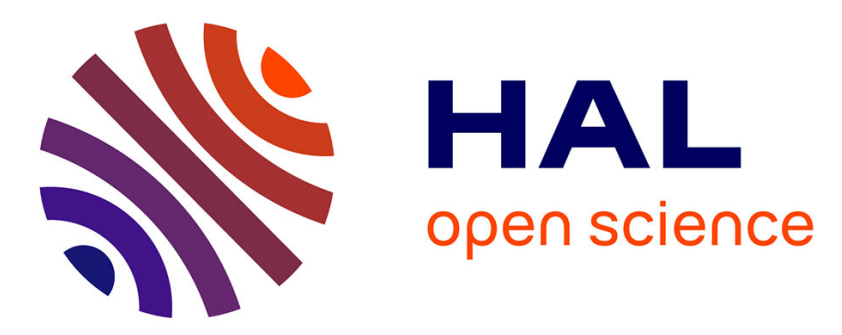

\title{
The uptake by crops of fresh and residual phosphatic fertilizers by simultaneous measurements with $32 \mathrm{P}$ and $33 \mathrm{P}$
}

\author{
Christian Morel, Jean-Claude Fardeau
}

\section{- To cite this version:}

Christian Morel, Jean-Claude Fardeau. The uptake by crops of fresh and residual phosphatic fertilizers by simultaneous measurements with $32 \mathrm{P}$ and $33 \mathrm{P}$. The International journal of applied radiation and isotopes, 1989, 4 (40), pp.273-278. 10.1016/0883-2889(89)90217-7 . hal-01701596

\section{HAL Id: hal-01701596 \\ https://hal.science/hal-01701596}

Submitted on 5 Feb 2018

HAL is a multi-disciplinary open access archive for the deposit and dissemination of scientific research documents, whether they are published or not. The documents may come from teaching and research institutions in France or abroad, or from public or private research centers.
L'archive ouverte pluridisciplinaire HAL, est destinée au dépôt et à la diffusion de documents scientifiques de niveau recherche, publiés ou non, émanant des établissements d'enseignement et de recherche français ou étrangers, des laboratoires publics ou privés. 


\title{
The Uptake by Crops of Fresh and Residual Phosphatic Fertilizers by Simultaneous Measurements with ${ }^{32} \mathrm{P}$ and ${ }^{33} \mathrm{P}$
}

\author{
C. MOREL ${ }^{1}$ and J. C. FARDEAU ${ }^{2 *}$ \\ 'COFAZ, Service Agronomique, BP 133, 92202 Neuilly sur Seine, France and ${ }^{2}$ DB/SRA, CEN Cadarache, \\ 13108 Saint-Paul-lez-Durance, France
}

(Received 23 June 1988; in revised form 1 November 1988)

\begin{abstract}
The effects of various residual $\mathrm{P}$ fertilizers, with or without fresh fertilizers cannot be measured directly by field or pot experiments. A radiotracer technique using ${ }^{32} \mathrm{PO}_{4}$ and ${ }^{33} \mathrm{PO}_{4}$ is described. Available soil phosphorus is ${ }^{32} \mathrm{P}$-labelled and fresh $\mathrm{P}$ fertilizer is ${ }^{33} \mathrm{P}$-labelled. Counting ${ }^{33} \mathrm{P}$ and ${ }^{32} \mathrm{P}$ in crops is carried out by measurements making use of the Cerenkov effect and using liquid scintillation procedures. From the results obtained in the example given, it can be concluded that the various kinds of residual P fertilizers can modify the uptake of the fresh P fertilizers applied.
\end{abstract}

\section{Introduction}

Only $1-20 \%$ of the phosphorus contained in P fertilizers is taken up by crops during the first year after their spreading (Engelstad and Terman, 1980; Fardeau, 1984). Therefore $80-99 \%$ remains in the soil and reacts with soil components, thus becoming "residual P". Knowledge of the effect of this residual phosphorus, the so-called "residual effect", is of a great interest for fertilization management (Barrow, 1980; Sanchez and Uehara, 1980). The percent of $P$ utilization of a phosphatic fertilizer (PPU\%) can easily be determined by isotopic labelling immediately after spreading (Dean et al., 1947); but, due to the fact that the half-life of the two phosphorus isotopes of agronomical interest, ${ }^{32} \mathrm{P}$ and ${ }^{33} \mathrm{P}$, is too short, the "residual effect" cannot be measured by the direct method of fertilizer labelling. A large amount of research has been conducted over the years on the agronomic evaluation of residual $P$ but has been frustrated by the flagrant lack of significant yield response. The purpose of this report is to describe the measurements of the uptake of residual $\mathrm{P}$ with or without addition of new fresh $\mathrm{P}$ fertilizer, in terms of PPU\%, and especially in terms of phosphorus taken up by crops and derived from one of two or more sources of nutrient. The experiments are conducted with ${ }^{32} \mathrm{P}$ and ${ }^{33} \mathrm{P}$. The described method was applied to a neutral loamy soil which, over 15 years, had been annually treated with two kinds of phosphorus fertilizers (superphosphate and soft rock phosphate), at three different rates $(0,21.8$ and $43.6 \mathrm{kgP}$, $\mathrm{ha}^{-1} \mathrm{y}^{-1}$ ) and a fresh fertilization of ${ }^{33} \mathrm{P}$-labelled triple superphosphate, at $\mathrm{P}$ contents of 0 and $33 \mathrm{ppm}$ during the pot experiment.

\section{Material and Methods}

\section{Methods}

\section{(A) $P$ uptake from a fresh fertilizer}

The measurement of the uptake of a phosphatic fertilizer by a crop is carried out with a ${ }^{33} \mathrm{P}$ labelled fertilizer using the method of Dean et al. (1947). Calculations are based on the assumption that during cropping, the two sources of phosphorus for crops, namely available soil $P$ and fertilizer $P$, remain distinct. This system can be described as in Fig. 1.

Let $R_{33}$, as ${ }^{33} \mathrm{PO}_{4}$, and $Q$ be the total quantities of radioactivity and phosphorus in the freshly added fertilizer. Let $r_{33}$ and $q$ be the cropped quantities of radioactivity and phosphorus. Using the measurements of $R_{33}, r_{33}, Q$ and $q$, the following can be calculated:

-The percent of $P$ utilization of the fresh fertilizer,

$$
\left(\mathrm{PPU}_{\mathrm{ff}} \%\right): \mathrm{PPU}_{\mathrm{ff}} \%=100 .\left(r_{33} / R_{33}\right) \text {. }
$$

-The quantity $q_{\mathrm{ff}}$ of fresh fertilizer taken up by the crop, 


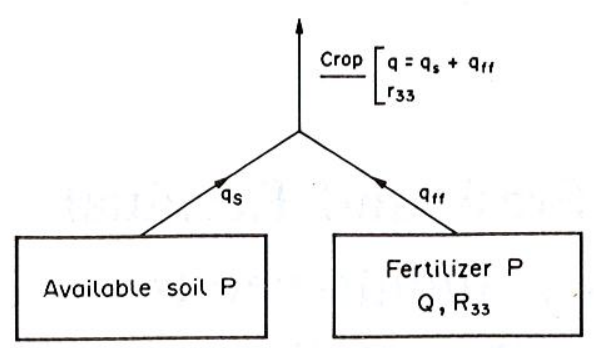

Fig. 1. Model for P nutrition with available soil phosphorus and fresh $\mathrm{P}$ fertilizer.

- The phosphorus in the crop derived from fresh fertilizer

$$
\left(\mathrm{PDF}_{\mathrm{ff}} \%\right): \mathrm{PDF}_{\mathrm{ff}} \%=\left(q_{\mathrm{ff}} / Q\right) 100,
$$

which, according to Fardeau (1984), is equivalent to

$$
\mathrm{PDF}_{\mathrm{ff}} \%=\left(\mathrm{RAS}_{q} / \mathrm{RAS}_{Q}\right) 100
$$

where RAS is the specific radioactivity of phosphorus in the crop $\left(\operatorname{RAS}_{q}\right)$ and in fertilizer $\left(\mathrm{RAS}_{Q}\right)$.

These various data can also be determined by an indirect method using labelling of the available $\mathrm{P}$ in soil (Fardeau et al., 1983).

\section{(B) $P$ uptake from residual fertilizers}

If, over many years, $P$ inputs due to fertilization are higher than $\mathrm{P}$ uptake by crops, as very frequently occurs in the intensive agriculture of North-Western European (Larsen, 1973) an increase, $\Delta \mathrm{P}$, in the total $\mathrm{P}$ in the plough soil layer arises. This increase, $\Delta \mathrm{P}$, sometimes induces an increase in the available soil $\mathrm{P}$. The estimation of the increase in the available soil $P$ is always made either by chemical extractants or by crop analysis. But as available soil phosphorus was chemically identified (Larsen, 1967; Fardeau and Jappe, 1976) as isotopically exchangeable $\mathrm{PO}_{4}$ ions, $\mathrm{L}$, determined according to the LARSEN method (Larsen, 1952), the increase, $\Delta \mathrm{L}$, of the available soil phosphorus, $\mathrm{L}+\Delta \mathrm{L}$, of the soil with phosphate residues can be determined and compared to $\Delta \mathrm{P}$, as well as the uptake of $\mathrm{P}$ from $\Delta \mathrm{L}$ and $\Delta \mathrm{P}$. But, as without the isotopic method, estimation of the residual effect is possible if, and only if, soil samples with and without residual $P$ fertilizers are available. These should be taken, for example, in long term trials using $\mathrm{P}$ fertilization.

1. Measurement without fresh fertilizer. The model used for calculations is shown in Fig. 2.

Let

$\mathrm{L}$ be the quantity of available soil $\mathrm{P}$ determined according to the Larsen method in soil without residual $\mathrm{P}$ (System $\mathrm{A}$ ).

$r_{32}$ and $q$ be the quantities of radioactivity and phosphorus of the crop on soil without residual $P$.

$\mathrm{L}+\Delta \mathrm{L}$ be the quantity of available $\mathrm{P}$ in soil with residual $\mathrm{P}$ (System $\mathrm{B}$ ).

$r_{32}^{\prime}$ and $q^{\prime}$ be the quantities of radioactivity and phosphorus of the crop in soil with residual $P$.

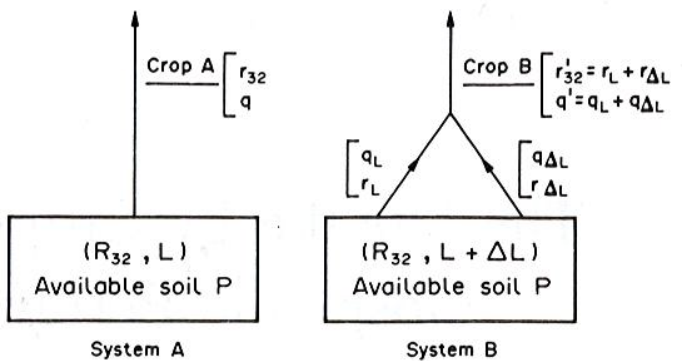

Fig. 2. Model for $\mathbf{P}$ nutrition with native available soil phosphorus and residual $\mathrm{P}$ fertilizer.

$R_{32}$ be the radioactivity quantity in systems $\mathrm{A}$ and $B$ for the labelling of available $\mathrm{P}, \mathrm{L}$ and $\mathrm{L}+\Delta \mathrm{L}$, respectively,

$\Delta \mathrm{P}$ be the increase of total $\mathrm{P}$ in soil, due to residual $\mathrm{P}$, between systems $\mathrm{A}$ and $\mathrm{B}$.

In crop $\mathrm{B}, r_{32}^{\prime}=r_{\mathrm{L}}+r_{\Delta \mathrm{L}}$, where $r_{\mathrm{L}}$ is the radioactivity taken up from $\mathrm{L}$ and $r_{\Delta \mathrm{L}}$ is the radioactivity taken up from $\Delta \mathrm{L}$. A similar relation, $q^{\prime}=q_{\mathrm{L}}+q_{\Delta \mathrm{L}}$, is useful for P uptake.

From Larsen's assumption, it can be deduced that:

$$
\begin{aligned}
& \text { From crop A: } \quad\left(r_{32} / q\right)=\left(R_{32} / \mathrm{L}\right) \\
& \text { From crop B: }\left(r_{32}^{\prime} / q^{\prime}\right)=\left(R_{32} / \mathrm{L}+\Delta \mathrm{L}\right)
\end{aligned}
$$

and from the Fried assumption (Fried and Dean, 1952), it can be deduced for crop B:

$$
\begin{aligned}
\left(q_{\mathrm{L}} / \mathrm{L}\right) & =\left(q_{\Delta \mathrm{L}} / \Delta \mathrm{L}\right) \\
& =\left(q_{\mathrm{L}}+q_{\Delta \mathrm{L}}\right) /(\mathrm{L}+\Delta \mathrm{L})=q^{\prime} /(\mathrm{L}+\Delta \mathrm{L}) .
\end{aligned}
$$

Therefore using the measurements of $R_{32}, r_{32}, r_{32}^{\prime}, q$ and $q^{\prime}, \Delta \mathrm{P}$ and the various relations, the following can be calculated:

- The $\mathrm{PDF}_{\mathrm{rf}} \%$, i.e. the phosphorus taken up by the crop and derived from residual phosphorus:

$$
\begin{aligned}
\operatorname{PDF}_{\mathrm{rf}} \% & =100\left(q_{\Delta \mathrm{L}} / q^{\prime}\right) \\
& =100\left[\left(q^{\prime} / r_{32}^{\prime}\right)-\left(q / r_{32}\right)\right] /\left(q^{\prime} / r_{32}^{\prime}\right)
\end{aligned}
$$

or

$$
\mathrm{PDF}_{\mathrm{rf}} \%=100\left[1-\left(\mathrm{RAS}_{q}^{\prime} / \mathrm{RAS}_{q}\right)\right]
$$

-The $\mathrm{PPU}_{\mathrm{rf}} \%$ of $\Delta \mathrm{P}$ which equals $\left(q_{\Delta \mathrm{L}} / \Delta \mathrm{P}\right) 100$

$$
\left.\mathrm{PPU}_{\mathrm{rf}} \%=\left(q^{\prime} / \Delta \mathrm{P}\right) \cdot\left[1-\mathrm{RAS}_{q}^{\prime} / \operatorname{RAS}_{q}\right)\right] 100 .
$$

It appears that the $\mathrm{PDF}_{\mathrm{rf}}$ can be estimated, as in many applications of the isotopic dilution method, only by determinations of RAS on aliquots of the crops.

2. Measure of residual effect in the presence of a fresh fertilizer. The $\mathrm{P}$ nutrition of a crop can be described as in Fig. 3. Available soil phosphorus is ${ }^{32} \mathrm{PO}_{4}$ labelled and the fresh fertilizer is ${ }^{33} \mathrm{PO}_{4}$ labelled.

The purpose is to measure the PPU\% and the $\mathrm{PDF} \%$ of the fresh and the residual phosphorus. The calculations of the $\mathrm{PPU}_{\mathrm{ff}} \%$ and $\mathrm{PDF}_{\mathrm{ff}} \%$ are conducted as in model I. The calculations of the $\mathrm{PPU}_{\mathrm{rf}} \%$ and $\mathrm{PDF}_{\mathrm{rf}} \%$ are performed based on the values of $q_{\mathrm{ff}}$ and $q_{\mathrm{ff}}^{\prime}$, and the quantities of $\mathrm{P}$ are derived from the 

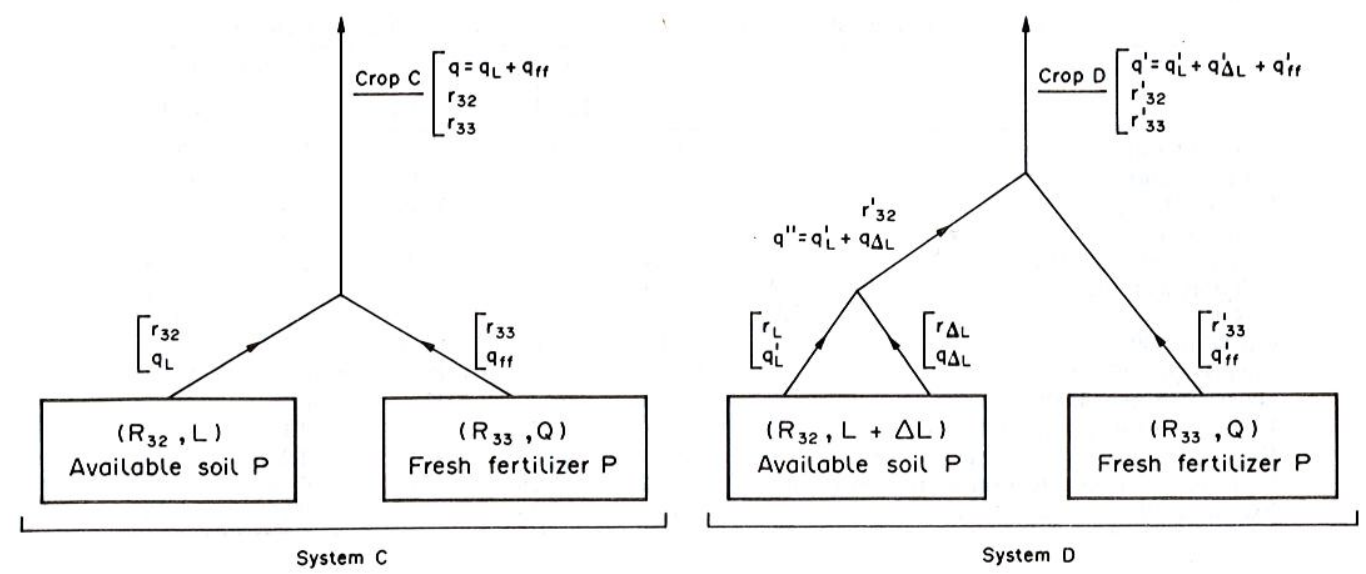

Fig. 3. Model for $\mathrm{P}$ nutrition with native available soil phosphorus, residual $\mathrm{P}$ fertilizer and fresh $\mathrm{P}$ fertilizer.

fresh fertilizer without and with residual $P$ respectively. When these values are known, $q_{\mathrm{L}}$ and $q_{\mathrm{L}+\Delta \mathrm{L}}$, i.e. the quantities of phosphorus taken up from available soil $P$ without and with residual phosphorus, can be calculated.

It can be deduced, as previously described in model II, that the $\mathrm{PDF}_{\mathrm{rf}} \%$ of $\Delta \mathrm{P}$ equals:

$$
\operatorname{PDF}_{\mathrm{rf}} \%=100\left[\left(q^{\prime \prime} / r_{32}^{\prime}\right)-\left(q_{\mathrm{L}} / r_{32}\right)\right] /\left(q^{\prime \prime} / r_{32}^{\prime}\right)
$$

where

and

$$
q_{\mathrm{L}}=q-\left(Q \cdot r_{33}\right) / R_{33}
$$

$$
q^{\prime \prime}=q^{\prime}-\left(r_{33}^{\prime} / R_{33}\right),
$$

and, as in model II,

$$
\mathrm{PPU}_{\mathrm{rf}} \%=q_{\Delta \mathrm{L}}^{\prime} / \Delta \mathrm{P}=\left(q^{\prime} \cdot \mathrm{PDF}_{\mathrm{rf}} \%\right) / \Delta \mathrm{P} .
$$

\section{(C) Experimental procedure}

Two treatments must be carried out for each soil sample with different types and contents of residual phosphorus fertilizers:

(i) In the first treatment, available soil phosphate is ${ }^{32} \mathrm{PO}_{4}$-labelled. This labelling is realized by isotopic exchange according to Larsen (Fardeau and Triboi, 1974), by manual or automatic mixing of soil, sieved at $2 \mathrm{~mm}$, with a ${ }^{32} \mathrm{PO}_{4} \mathrm{H}_{3}$ carrier-free solution. The solution containing $0.06 \mathrm{MBq} \mathrm{mL}^{-1}$ was added using $50 \mathrm{~mL} \mathrm{~kg}^{-1}$ of dry soil. Five kilograms of soil were prepared at the same time. This treatment corresponds to systems A and B in model II.

(ii) In the second treatment, for which available soil phosphate has been ${ }^{32} \mathrm{PO}_{4}$-labelled as previously, ${ }^{33} \mathrm{PO}_{4}$-labelled triple superphosphate in solid form was added to give a $\mathrm{P}$ content of $33 \mathrm{ppm}$. Any other $P$ fertilizers can be used to provide fresh fertilizer. This treatment corresponds to systems C and D in model III.

After mixing, $1 \mathrm{~kg}$ of dry soil is put into pots. Each treatment was carried out on five samples. Soils were wetted at field capacity and sown with $1 \mathrm{~g}$ Lolium perenne. Five cuts were carried out at three weekly intervals. After each cutting, $60 \mathrm{ppm}$ of nitrogen and potassium were supplied using ammonium nitrate and potassium sulfate.

After each cutting, samples were dried and weighed. Total phosphorus uptakes and total radioactivity were determined after mineralization of each sample. ${ }^{32} \mathrm{P}$ and ${ }^{33} \mathrm{P}$ were measured by using the Cerenkov effect and scintillation procedures respectively.

\section{Soil Samples}

These were collected in a long term field experiment conducted by the Institut National de la Recherche Agronomique and located in the Department of Aisne. Their main characteristics are given in Table 1. This experimental design was 15 years old. Various phosphatic fertilizers were compared, especially superphosphate and rock phosphate at annual rates of 0,50 and $100 \mathrm{kgP}_{2} \mathrm{O}_{5} \mathrm{ha}^{-1}$.

\section{Results}

\section{(A) Dry matter yield and phosphorus uptake}

They were summed for the five successive cuts and are reported in Table 2.

The variations in dry matter yields were too low to authorize conclusions about the effect of residual phosphorus with or without fresh P fertilizers. This result is similar to that obtained in numerous field experiments. It can be concluded that in this soil and with this crop, phosphorus did not appear as the first limiting factor for dry matter crop production.

Phosphorus uptake differed with different treatments. Fresh P fertilization increased P uptakes and, without the fresh P-fertilization, P uptake by crop was greatly increased with $\mathrm{P}$ residues of superphosphate spread at $100 \mathrm{~kg} \mathrm{P}_{2} \mathrm{O}_{5}$ ha $^{-1}$.

\section{(B) Specific radioactivity of $P$ in crops}

As the values of the PPU\% and $\mathrm{PDF}_{\mathrm{ff}} \%$ or $\mathrm{PDF}_{\mathrm{rf}} \%$ can be calculated from values of the specific radioactivity of phosphorus (RAS), these data are 
Table 1. Main soil characteristics (Level 1: $50 \mathrm{~kg} \mathrm{P}_{2} \mathrm{O}_{5} \mathrm{ha}^{-1}$; level 2: $100 \mathrm{~kg} \mathrm{P}_{2} \mathrm{O}_{5} \mathrm{ha}^{-1}$ )

\begin{tabular}{|c|c|c|c|c|c|}
\hline \multirow[b]{2}{*}{ Residual P } & \multirow[b]{2}{*}{0} & \multicolumn{2}{|c|}{ Superphosphate } & \multicolumn{2}{|c|}{ Rock phosphate } \\
\hline & & Level 1 & Level 2 & Level 1 & Level 2 \\
\hline Clay $(<2 \mu \mathrm{m})$ & 11.7 & 14.4 & 14.8 & 11.6 & 12.6 \\
\hline Silt $(2-20 \mu \mathrm{m})$ & 32.6 & 32.2 & 32.9 & 32.4 & 32.8 \\
\hline Silt $(20-50 \mu \mathrm{m})$ & 50.0 & 49.1 & 47.0 & 47.0 & 47.6 \\
\hline Sand $(>50 \mu \mathrm{m})$ & 5.7 & 4.3 & 5.3 & 9.0 & 7.0 \\
\hline Organic matter (P.100) & 1.29 & 1.35 & 1.39 & 1.37 & 1.39 \\
\hline N Kjeldahl (P.1000) & 0.75 & 0.80 & 0.81 & 0.84 & 0.84 \\
\hline $\mathrm{C} / \mathrm{N}$ & 10.0 & 9.9 & 10.0 & 9.5 & 9.6 \\
\hline $\mathrm{CaCO}_{3}(\mathrm{P} .100)$ & 0.0 & 0.0 & 0.0 & 0.3 & 0.7 \\
\hline Total-P (ppm P205) & 1005 & 939 & 1126 & 1110 & 1253 \\
\hline NaHCO3-P (ppm P205) & 44 & 42 & 66 & 40 & 33 \\
\hline Exchange capacity (m-equiv $\left.(100 \mathrm{~g})^{-1}\right)$ & 6.9 & 7.2 & 7.2 & 7.1 & 6.9 \\
\hline Exchangeable calcium (m-equiv $\left.(100 \mathrm{~g})^{-1}\right)$ & 15.7 & 11.3 & 10.5 & 13.2 & 20.4 \\
\hline Exchangeable magnesium (m-equiv $\left.(100 \mathrm{~g})^{-1}\right)$ & 0.26 & 0.26 & 0.26 & 0.28 & 0.32 \\
\hline Exchangeable potassium (m-equiv $(100 \mathrm{~g})^{-1}$ ) & 0.26 & 0.28 & 0.28 & 0.25 & 0.35 \\
\hline
\end{tabular}

Table 2. Dry matter yield and $P$ uptake ( 5 cuts summed up). (Data followed by different letters are significantly different: $P=0.05$ )

\begin{tabular}{|c|c|c|c|c|c|}
\hline \multirow[b]{2}{*}{ Residual P } & \multirow[b]{2}{*}{0} & \multicolumn{2}{|c|}{ SSP residues } & \multicolumn{2}{|c|}{$\mathrm{RP}$ residues } \\
\hline & & Level 1 & Level 2 & Level 1 & Level 2 \\
\hline $\begin{array}{l}\text { Dry matter }(\mathrm{g}) \text { yield } \\
+ \text { TSP }\end{array}$ & $\begin{array}{l}3.81 \mathrm{c}+ \\
4.17 \mathrm{bc}\end{array}$ & $\begin{array}{l}4.21 \mathrm{bc} \\
4.27 \mathrm{bc}\end{array}$ & $\begin{array}{l}4.25 \mathrm{bc} \\
4.41 \mathrm{ab}\end{array}$ & $\begin{array}{l}4.35 \mathrm{ab} \\
4.44 \mathrm{ab}\end{array}$ & $\begin{array}{l}4.01 \mathrm{bc} \\
4.76 \mathrm{a}\end{array}$ \\
\hline $\begin{array}{c}\text { P uptake }(\mathrm{mg}) \\
+\mathrm{TSP}\end{array}$ & $\begin{array}{l}15.3 \mathrm{e} \\
19.2 \mathrm{c}\end{array}$ & $\begin{array}{l}16.4 \mathrm{de} \\
19.4 \mathrm{c}\end{array}$ & $\begin{array}{l}22.2 \mathrm{~b} \\
25.4 \mathrm{a}\end{array}$ & $\begin{array}{l}17.8 \mathrm{~cd} \\
22.8 \mathrm{~b}\end{array}$ & $\begin{array}{l}13.5 \mathrm{f} \\
21.8 \mathrm{~b}\end{array}$ \\
\hline
\end{tabular}

given in Tables 3 and 4. For an easier comparison of the various results, the RAS values are calculated as follows; $(100 \cdot r / R) / p$, where $r$ and $p$ are the quantities of radioactivity and phosphorus, and where $R$ is the quantity of radioactivity in the labelled source of nutrient.

According to this assumption, RAS of the ${ }^{33} \mathrm{P}$ labelled fertilizer was $(100 \cdot 100 / 100) / 33=3.33 \mathrm{mg}^{-1 \mathrm{p}}$.

${ }^{33} P-R A S$ in crop. The calculated values are shown in Table 3. They were given for the five cuts and for the total phosphorus uptake. Only rock phosphate, as residual fertilizer at $100 \mathrm{~kg} \mathrm{P}_{2} \mathrm{O}_{5} \mathrm{ha}^{-1}$ induced a significantly different result.
${ }^{32} P-R A S$. Two ${ }^{32} \mathrm{P}-\mathrm{RAS}$ can be calculated. The first is related to the total $P$ in the crop and the second is related to the phosphorus taken from the available soil phosphorus which was ${ }^{32} \mathrm{P}$-labelled. This last RAS is known from the total $\mathrm{P}$ in the crop decreased by the phosphorus taken up from the fresh ${ }^{33} \mathrm{P}$-fertilizer. Since only the RAS of the phosphorus taken up from the available soil $\mathrm{P}$ is useful in calculating the $\mathrm{PPU}_{\mathrm{rf}} \%$ and $\mathrm{PDF}_{\mathrm{rf}} \%$, these data are given directly in Table 4. These data are the mean values of the 10 similar samples, five with and five without fresh fertilizer. This data was modified only by the use of residual $\mathrm{P}$ from superphosphate at $100 \mathrm{~kg} \mathrm{P}_{2} \mathrm{O}_{5} \mathrm{ha}^{-1}$.

Table 3. Specific activity of phosphorus in crop with ${ }^{33} \mathrm{P}$-labelled fresh fertilizer. (Data followed by the same letter: homogen group at $P=0.05$ )

\begin{tabular}{|c|c|c|c|c|c|}
\hline \multirow[b]{2}{*}{ Cut no. } & \multirow[b]{2}{*}{0} & \multicolumn{2}{|c|}{ Superphosphate } & \multicolumn{2}{|c|}{ Rock phosphate } \\
\hline & & Level 1 & Level 2 & Level 1 & Level 2 \\
\hline 1 & 0.37 & 0.45 & 0.39 & 0.48 & 0.64 \\
\hline 2 & 0.48 & 0.55 & 0.49 & 0.68 & 0.82 \\
\hline 3 & 0.50 & 0.57 & 0.54 & 0.71 & 0.84 \\
\hline 4 & 0.41 & 0.47 & 0.49 & 0.63 & 0.69 \\
\hline 5 & 0.42 & 0.43 & 0.47 & 0.57 & 0.62 \\
\hline Mean & $0.43 \mathrm{~B}$ & $0.50 \mathrm{~B}$ & $0.47 \mathrm{~B}$ & $0.60 \mathrm{AB}$ & $0.73 \mathrm{~A}$ \\
\hline
\end{tabular}

Table 4. Specific activity of phosphorus in crop derived from available soil phosphorus without or with fresh fertilizer. (Data followed by the same letter: homogen group at $P=0.05$ )

\begin{tabular}{ccccccc}
\hline & & \multicolumn{2}{c}{ Superphosphate } & & \multicolumn{2}{c}{ Rock phosphate } \\
\cline { 3 - 4 } \cline { 6 - 7 } Cut no. & 0 & Level 1 & Level 2 & & Level 1 & Level 2 \\
\hline 1 & 1.26 & 1.13 & 0.83 & & 1.07 & 1.12 \\
2 & 1.51 & 1.34 & 0.98 & & 1.40 & 1.52 \\
3 & 1.42 & 1.25 & 0.88 & & 1.27 & 1.40 \\
4 & 1.24 & 1.10 & 0.78 & & 1.09 & 1.19 \\
5 & 1.21 & 1.10 & 0.78 & & 1.03 & 1.10 \\
Mean & $1.32 \mathrm{~A}$ & $1.19 \mathrm{~A}$ & $0.87 \mathrm{~B}$ & & $1.16 \mathrm{~A}$ & $1.26 \mathrm{~A}$ \\
\hline
\end{tabular}




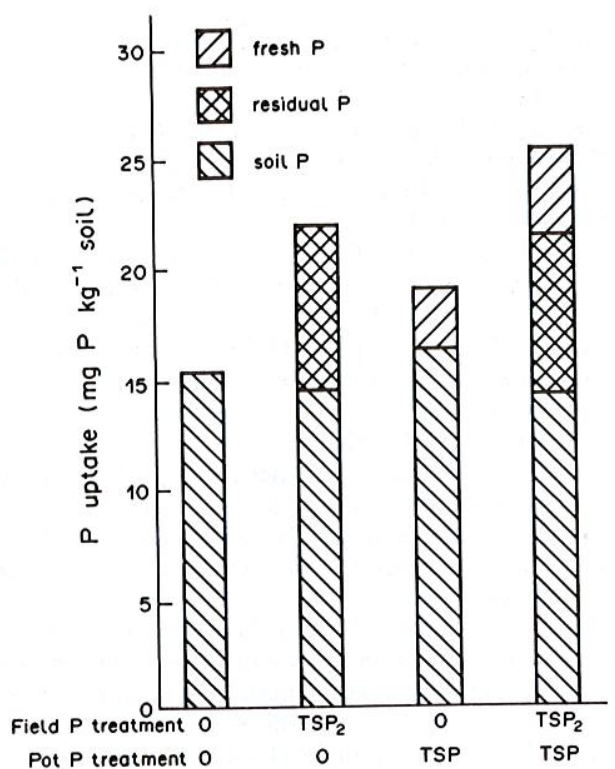

Fig. 4. $P$ in crop derived from native available soil phosphorus, residual $\mathrm{P}$ fertilizer and fresh $\mathrm{P}$ fertilizer.

\section{Discussion}

(A) Phosphorus in crops is derived from available soil $P$, and fresh and residual fertilizer applied as superphosphate at $100 \mathrm{~kg} \mathrm{P}_{2} \mathrm{O}_{5} \mathrm{ha}^{-1}$

Phosphorus derived from available soil $\mathrm{P}$ and residual and fresh fertilizer are shown in Fig. 4. Without fresh fertilizer, $\mathrm{PDF}_{\mathrm{rf}}, \%$ of the residual $\mathrm{P}$ reached $34 \%$. With the application of a fresh fertilizer, with a $\mathrm{P}$ content of $33 \mathrm{ppm}$, the cropped phosphorus taken up from fresh $\mathrm{P}$ was $15 \%$, from residual P $29 \%$ and from the native soil phosphorus $56 \%$. The $\mathrm{PPU}_{\mathrm{ff}}$ of the fresh fertilizer was, in this last case, $11.8 \%$ and the $\mathrm{PPU}_{\mathrm{rf}}$ was only $3.5 \%$. These low values can be explained by the phosphorus fixing capacity of the soil.

\section{(B) Effect of residual $P$ on available soil phosphorus}

This effect can be estimated from the kinetics of the ${ }^{32} \mathrm{P}$-RAS which give the isotopic composition of the phosphorus derived from the available soil phosphorus with or without residual P-fertilizers. These kinetics are shown in Fig. 5. All these kinetics are similar. The lower values obtained during the first cut are due to the phosphorus derived from Lolium seeds (Binh Truong and Pichot, 1976) which significantly decreases the RAS of the phosphorus derived from the available soil $P$. The decrease of the P-RAS at the second cut is due partly to the continuation of the isotopic exchange (Fardeau et al., 1985) and partly to a desorption of phosphate ions from soil (Roche, 1983).

As annual input of rock phosphate at 50 and $100 \mathrm{~kg} \mathrm{P}_{2} \mathrm{O}_{5} \mathrm{ha}^{-1}$ and superphosphate at $50 \mathrm{~kg} \mathrm{P}_{2} \mathrm{O}_{5}$ $\mathrm{ha}^{-1}$ did not significantly modify the ${ }^{32} \mathrm{P}-\mathrm{RAS}$ in crops, it can be concluded that available soil $\mathrm{P}$ was not increased in these treatments. For this reason, the

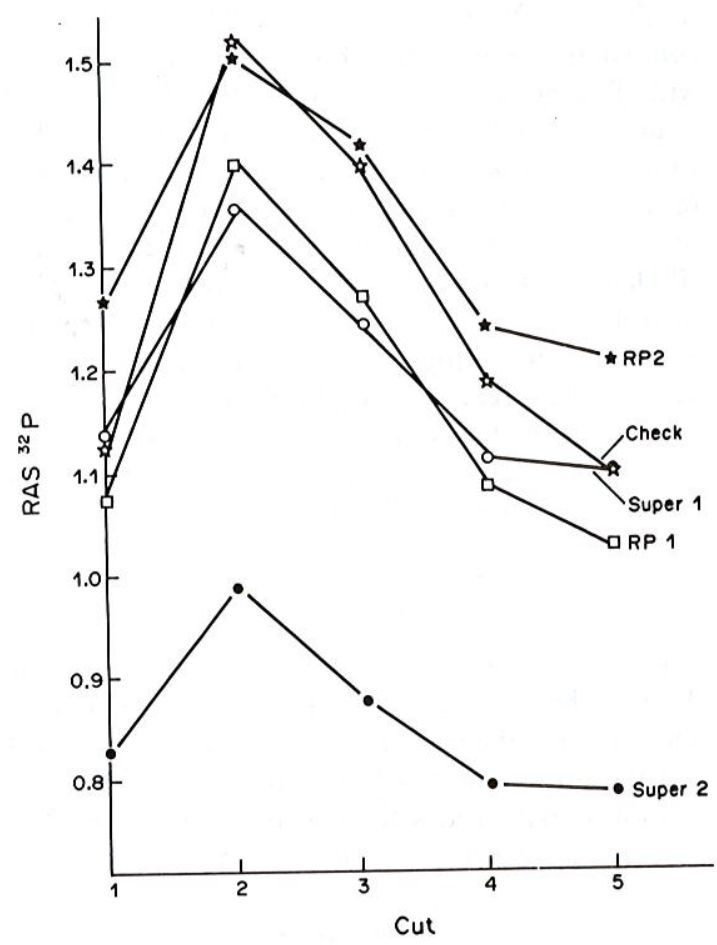

Fig. 5. Kinetics of the RAS of $P$ in crop derived from available soil phosphorus.

$\mathrm{PDF}_{\mathrm{rf}} \%$ and the $\mathrm{PPU}_{\mathrm{rf}} \%$ are not significantly different from zero. This clear result is similar and can explain numerous field experiments. Moreover, as the P-RAS of $\mathrm{P}$ cropped on soil without $\mathrm{P}$ fertilization did not significantly differ from P-RAS of $\mathbf{P}$ cropped on soil with rock phosphate, it also can be concluded that there was no specific dissolution of rock phosphate in the Lolium perenne rhizosphere (Heck and Saive, 1983).

In this soil, only superphosphate at an annual rate of $100 \mathrm{~kg} \mathrm{P}_{2} \mathrm{O}_{5} \mathrm{ha}^{-1}$ increased the available soil P. In this treatment the $\mathrm{PDF}_{\mathrm{rf}} \%$ was $38 \%$ and the $\mathrm{PPU}_{\mathrm{rf}} \%$ was $3.9 \%$, a very low value.

(C) Influence of the various residual $P$ fertilizers on the uptake of the fresh fertilizer applied as superphosphate

Input of fresh fertilizer, as superphosphate i.e. a water soluble form, increased total $P$ uptake by crops but decreased the gaps between the various treatments. These results are in accordance with those published based on field experimental data (Bolland and Bowden, 1984; Boniface and Trocme, 1988). A part of the increase in $P$ uptake was due to the utilization of the fresh fertilizer, and part was due to the available soil $P$ and could be explained by greater soil exploration (Morel et al., 1987). The kinds of residual $\mathrm{P}$ had modified the uptake of the fresh fertilizer. The increase of $P$ uptake with the fresh $P$ added at a $P$ content of $33 \mathrm{ppm}$ rate was higher for soil samples which have received annual applications of rock phosphates. This result could be explained not only by the greater utilization of the fresh 
fertilizer but also by a greater uptake from the soil compared to soil without $\mathrm{P}$ residues. In comparison, with $\mathbf{P}$ superphosphate residues the increase of $\mathrm{P}$ uptake came only from the fresh fertilizer. These data show the interaction between fresh $\mathrm{P}$ and kinds of residual $\mathbf{P}$ on $\mathrm{P}$ nutrition. In field experiments, effects of residual $P$ are usually tested using a fresh fertilizer (Bolland and Bowden, 1984; Bolland et al., 1984; Sharpley, 1987). But, as shown by numerous isotopic labelling, only isotopic determination can accurately identify the origin of phosphorus in crops which can depend on the kinds of residual P fertilizers. So field experiments cannot give precise information about the various source of phosphorus for crops.

\section{Conclusion}

In order to understand the P-nutrition in crops, the double labelling technique was used with ${ }^{32} \mathrm{P}$ and ${ }^{33} \mathrm{P}$. The results obtained made it clear that crop $\mathrm{P}$ nutrition in the field with old and fresh $P$ fertilizers cannot be explained without knowledge of the effects of the various sources of $\mathrm{P}$ for crop nutrition.

\section{References}

Barrow N. J. (1980) Evaluation and utilization of residual phosphorus in soil. In The Role of Phosphorus in Agriculture, p. 333. American Society of Agronomy, Madison.

Binh Truong and Pichot J. (1976) Influence du phosphore des graines de la plante test sur la determination du phosphore isotopiquement diluable (valeur L). In 6 Congres International sur la Fertilisation, p. 234. Moscow.

Bolland M. D. A. and Bowden J. W. (1984) The initial value and residual value for subterranean clover of phosphorus from crandallite rock phosphates, apatite rock phosphates and superphosphate. Fert. Res. 5, 295.

Bolland M. D. A., Bowden J. W., D'Antuano M. F. and Gilkes R. J. (1984) The current and residual value of superphosphate, Christmas island ore and calciphos as fertilizers for a subterranean clover pasture. Fert. Res. 5, 535.

Boniface R. and Trocme S. (1988) Essais sur la fumure phosphatée. In Phosphore et Potassium dans les Relations Sol-plante: Conséquences sur la Fertilisation. INRA, Paris.

Dean L. A., Nelson W. L., Mackensie A. J., Armiger W. H. and Hill W. L. (1947) Application of radioactive tracer technique to studies of phosphatic fertilizer utilization by crops: I. Greenhouse experiments. Soil Sci. Soc. Amer. Proc. 12, 107.

Engelstad O. P. and Terman G. L. (1980) Agronomic effectiveness of phosphatic fertilizers. In The Role of Phosphorus in Agriculture, p. 311. American Society of Agriculture, Madison.

Fardeau J. C. (1984) Results of direct measures of the utilization coefficient in fertilizers by isotopic labelling with ${ }^{32} \mathrm{P},{ }^{15} \mathrm{~N}$ and ${ }^{40} \mathrm{~K}$. Fert. Agric. 86, 23.

Fardeau J. C. and Jappe J. (1976) Nouvelle methode de determination du phosphore assimilable par les plantes: extrapolation des cinétiques de dilution isotopique. C.R. Acad. Sci. Paris D 282, 1137.

Fardeau J. C., Migadel F., Gjermani A. (1983) Efficacité d'un phosphate à faible teneur dans quelques sols d'Albanie mesurée au moyen de ${ }^{32} \mathrm{P}$. In Third Int. Congress on Phosphorus Compounds Proc. p. 519. Imphos, Casablanca.

Fardeau J. C., Morel C. and Jappe J. (1985) Cinétique d'échange des ions phosphate dans les systèmes sol-solution. Vérification expérimentale de l'éluation théorique. C.R. Acad. Sci. Paris III 300, 8, 371.

Fardeau J. C. and Triboi E. (1974) Mesure au champ du phosphore disponible "L". Plant Soil 41, 293.

Fried M. and Dean L. A. (1952) A concept concerning the measurement of available soil nutrients. Soil Sci. 73, 263.

Heck J. P. and Saive R. (1983) Microflore rhizosphérique et utilisation des phosphates minéraux des sols par les plantes de grande culture. In Third Int. Congress on Phosphorus Compounds Proc., p. 455. Imphos, Casablanca.

Larsen S. (1952) The use of ${ }^{32} \mathrm{P}$ in studies on the uptake of phosphorus by plants. Plant Soil. 4, 1.

Larsen S. (1967) Soil phosphorus. Adv. Agron. 19, 151.

Larsen S. (1973) Recyclage de $\mathrm{P}$ en relation avec les réserves à long terme du sol. Phosphore Agric. 61, 1 .

Morel C., Fardeau J. C. and Balland D. (1987) Efficiency of different phosphatic fertilizers using ${ }^{32} \mathrm{P}$. In Proc. of the IFA Regional Agricultural Meeting, p. 47. IFA, Paris.

Roche P. (1983) Les méthodes d'appréciation du statut phosphorique des sols. Leur application à l'estimation des besoins en engrais phosphatés. In Third Int. Congress on Phosphorus Compounds Proc. p. 165 . Imphos, Casablanca.

Sanchez P. A. and Uehara G. (1980) Management considerations for acid soils with high phosphorus fixation capacity. In The Role of Phosphorus in Agriculture, p. 471. American Society of Agronomy, Madison.

Sharpley A. N. (1987) Relative availabilities of native and residual fertilizer phosphorus to winter wheat. Soil Sci. Soc. Am. J. 51, 1531. 